\title{
HUBUNGAN PERSEPSI SISWA TENTANG KOMPETENSI LULUSAN YANG DIBUTUHKAN DI INDUSTRI DENGAN HASIL BELAJAR
}

\author{
Hary Sutanto ${ }^{1}$, Syafaruddin Siregar ${ }^{2}$, Yayat $^{3}$ \\ Departemen Pendidikan Teknik Mesin \\ Universitas Pendidikan Indonesia \\ Jl. Dr. Setiabudhi No. 207 Bandung 40154 \\ harysutanto@yahoo.com
}

\begin{abstract}
ABSTRAK
Tujuan penelitian ini adalah untuk mengetahui sebaran persepsi mahasiswa tentang kompetensi lulusan yang dibutuhkan industri, hasil belaajr dan hubungan antara persepsi mahasiswa tentenag pekerjaan dengan hasil belajar. Metode yang digunakan dalam penelitian ini adalah metode deskriptif korelasional. Hasil penelitian menunjukan bahwa persepsi siswa tentang kompetensi lulusan berada di kategori sedang, hasil menyebarluaskan data siswa belajar berada di kategori tinggi, dan hubungan antara persepsi siswa tentang kompetensi lulusan yang membutuhkan di industri untuk menghasilkan belajar yang menunjukkan nilai yang sangat rendah. Kesimpulan penelitian ini yaitu hubungan antara persepsi siswa tentang kompetensi lulusanyang diperlukan di industri dengan hasil belajar tidak signifikan.
\end{abstract}

Kata kunci: persepsi, lulusan, hasil belajar, industri, kompetensi

\section{PENDAHULUAN}

Sekolah Menengah Kejuruan merupakan lembaga pendidikan yang menyiapkan peserta didik agar menjadi manusia produktif, mampu bekerja mandiri, mengisi lowongan pekerjaan yang ada sebagai tenaga kerja tingkat menengah sesuai dengan kompetensi dalam program keahlian yang dipilihnya. Lulusan SMK seharusnya dapat dengan mudah terserap di industri karena telah di bekali dengan kompetensi sesuai dengan keahlian (Mangkunegara, 2004). Pada kenyataannya lulusan SMK menyumbang sebesar 11,24\% terhadap Tingkat Pengangguran Terbuka. Lebih besar dibanding dengan lulusan sekolah menengah atas (SMA) yang hanya 9,5\%. TPT ini mengindikasikan bahwa daya serap dunia kerja terhadap lulusan SMK masih kecil. Kecilnya keterserpan lulusan SMK oleh industri tidak sejalan dengan target Direktur Pembinaan SMK Kementerian Pendidikan Nasional yang metargetkan pada 2014 lulusan SMK bisa terserap 70 persen ke dunia kerja.

Permasalahan di atas mungkin terjadi karena jumlah lowongan pekerjaan yang tersedia lebih sedikit dibanding jumlah lulusan SMK. Selain itu, kemungkinan mutu lulusan yang belum seseuai dengan permintaan pasar (demand driven). Sehingga tidak ada

\footnotetext{
${ }^{1}$ Mahasiswa Departemen Pendidikan Teknik Mesin FPTK UPI

${ }^{2}$ Dosen Departemen Pendidikan Teknik Mesin FPTK UPI

${ }^{3}$ Dosen Departemen Pendidikan Teknik Mesin FPTK UPI
} 
ketersambungan (link) antara pengguna lulusan pendidikan dan penyelenggara pendidikan dan kecocokan (match) antara employee dengan employer. Mutu dan relevansi pendidikan dapat dilihat dengan mengikuti alur input-proses-output. Masukan dalam komposisi tertentu yang diproses dengan metode tertentu akan membuahkan dua macam hasil, yaitu hasil jangka pendek (hasil belajar) dan hasil jangka panjang (lulusan) (Sudjana, 2005). Permasalahan tentang daya serap lulusan oleh industri juga di alami SMKN 12 Bandung yang terus mengalami penurunan. Lulusan SMKN 12 Bandung pada tahun 2013/2014 mengalami penurunan sebesar 19,1\% dari tahun 2012/2013, dan sebesar 21,2\% dari tahun $2011 / 2012$.

Tingkat keterserapan lulusan SMK oleh industri tidak terlepas dari persyaratan yang ditetapkan oleh industri. Salah satu syarat tersebut adalah nilai Ujian Nasional yang tinggi. Contohnya PT Dirgantara Indonesia mensyaratkan Nilai Ujian Nasional untuk mata pelajaran bahasa. Indonesia, Bahasa Inggris, dan Matematika masing- masing minimal 7.0. Sementara hasil UN siswa SMKN 12 Bandung program keahlian PPU pada tahun 2013/2014 untuk ketiga mata pelajaran tersebut hanya 12,12\% yang memiliki nilai 7,0 ke atas, dan 87,88\% yang di bawah 7,0. Lulusan belum mampu memcapai kriteria minimal yang dittetapkan oleh pihak industri, yaitu 7,0. Kenyataan yang terjadi pada lulusan tersebut mengindikasikan bahwa siswa mengalami kesulitan belajar.

Hasil belajar merupakan hasil dari suatu interaksi tindak belajar dan tindak mengajar. Hasil belajar siswa di sekolah dipengaruhi oleh beberapa faktor, yaitu faktor intern dan faktor ekstern. Faktor faktor yang mempengaruhi proses dan hasil belajar siswa terdiri dari faktor intern dan faktor ekstern. Faktor intern yaitu faktor yang berasal dari dalam diri siswa itu sendiri, salah satunya adalah persepsi. Adapun faktor eksteren yaitu faktor yang ada dari luar diri siswa antara lain guru, orang tua, kurikulum, sarana dan prasarana belajar serta kondisi kelas (Dimyati dan Mudjiono, 2002).

Persepsi merupakan suatu proses yang dimulai dari pendeteksian panca indra hingga terbentuk tanggapan, ide, keyakinan, gagasan yang terjadi dalam diri individu. Individu sadar akan segala sesuatu dalam lingkungannya melalui indera-indera yang dimilikinya. Persepsi yang terbentuk pada siswa bisa berupa persepsi positif dan persepsi negatif. Persepsi dapat mempengaruhi sikap siswa karena persepsi merupakan salah satu komponen kognitif sikap (Suharman, 2005). Salah satu teori mengenai perubahan sikap yaitu perceptual theory approach (pendekatan teori persepsi), pendekatan teori ini beranggapan bahwa sikap seseorang itu berubah bila persepsinya tentang objek itu 
berubah. Sikap merupakan penguatan positif atau negatif terhadap objek yang bersifat psikologis (Sugihartono, 2007).

Jika siswa memiliki persepsi negatif tentang kompetensi yang harus dikuasai untuk dapat bekerja, maka siswa akan menunjukan sikap negatif terhadap hal tersebut. Sebaliknya jika siswa memiliki persepsi positif tentang kompetensi yang harus dikuasai untuk dapat bekerja, maka sikap siswa juga akan positif. Sehingga sikap dalam pembelajaran dan tidak akan membeda-bedakan antara mata pelajaran normatif dan adaftif dengan mata pelajaran praktek dan menganggap semua mata pelajaran wajib dipelajari dan dikuasai (Walgito, 2004).

Sikap menuntun perilaku siswa, sehingga siswa akan bertindak sesuai dengan sikap yang diekspresikan. Kesadaran individu untuk menentukan tingkah laku nyata dan perilaku yang mungkin terjadi. Berdasarkan pengamatan peneliti ketika melakukan PPL ditemui masalah mengenai sikap siswa diantaranya: terdapat siswa yang melanggar aturan (atribut sekolah tidak lengkap, datang kesiangan), sebagian siswa mengerjakan pekerjaan rumah di sekolah secara bersama sama. Pada saat praktek meniru pekerjaan teman yang sudah beres, ada sebagian siswa yang sudah berhenti praktek sebelum waktunya sehingga mengganggu ketepatan waktu pengerjaan. Pihak sekolah juga menerima masukan dari pihak industri terkait permintaan dunia industri untuk meningkatkan soft skill siswa terutama masalah disiplin, etos kerja, kreativitas, dan pengetahuan tentang kedirgantaraan yang masih perlu ditingkatkan (Simamora, 2001). Tujuan penelitian ini untuk mengetahui sebaran persepsi siswa tentang kompetensi lulusan yang dibutuhkan di industri, sebaran hasil belajar, hubungan antara persepsi siswa kompetensi lulusan yang dibutuhkan di industri dengan hasil belajar siswa.

\section{METODE PENELITIAN}

Metode yang digunakan dalam penelitian ini adalah metode deskriptif analisis. Jenis penelitian menggunakan pendekatan metode korelasional. Penelitian dilakukan untuk mengetahui tingkat hubungan antara dua variabel atau lebih, tanpa melakukan perubahan, tambahan atau manipulasi terhadap data yang memang sudah ada.

Penelitian ini berlokasi SMK Negeri 12 Bandung yang beralamat di Jalan. Pajajaran No. 92 Bandung. Khususnya di jurusan Pemesinan Pesawat Udara. Populasi dalam penelitian ini adalah seluruh siswa kelas XII semester ganjil Kompetensi Keahlian PPU di SMK Negeri 12 Bandung tahun ajaran 2014/2015. Jumlah populasi sebanyak 130 siswa, sampel yang diambil sebesar 25\% dari 130 yaitu sebanyak minimal 32 siswa. 


\section{HASIL PENELITIAN}

Hasil perhitungan uji validitas instrumen terdapat 20 item pernyataan tidak valid dan 40 soal yang valid. Hasil perhitungan uji reabilitas dengan Cronbach's Alpha atau $\mathrm{r}_{11}=$ 0,924. Sehingga dengan nilai alpha 0,924>0,6 tersebut dapat disimpulkan bahwa instrumen penelitian termasuk reliabilitas sangat tinggi.

Data persepsi siswa tentang kompetensi yang dibutuhkan di industri diperoleh melalui penyebaran instrumen penelitian dengan jumlah 60 soal. Penyebaran instrumen ini dilakukan pada siswa kelas XIII PPU 1 di SMKN 12 Bandung tahun ajaran 2014/2015. Setelah instrumen penelitian dikembalikan dan diperiksa secara teliti, kemudian instrumen tersebut diberi skor dengan skala 5 yang disesuaikan dengan jawaban responden. Hasil perhitungan terlihat bahwa persepsi siswa tentang kompetensi lulusan yang dibutuhkan di industri dengan banyak responden 31 orang, jumlah skor 1555, nilai tertinggi 70 dan terendah 32, dengan range 38, nilai rata-rata 50,16, serta standar deviasi 10,004. Persepsi siswa terhadap kompetensi lulusan yang dibutuhkan di industri pada skala data berada pada kategori sedang, yaitu berada pada rentang skort antara 47,2 sampai 54,8.

Data hasil belajar siswa, yang diperoleh dari nilai raport siswa yang kemudian dikonversikan ke dalam T-skor. Hasil perhitungan hasil belajar siswa dengan banyak responden 31 orang, di peroleh nilai tertinggi 67 dan terendah 18 dengan range 49, jumlah skor 1551, dengan nilai rata-rata 50,03 serta standar deviasi 9,938. Hasil belajar pada skala data berada pada kategori tinggi, yaitu berada pada rentang skor antara 49,2 sampai 59,9 .

Analisis data dilakukan untuk mengolah data serta pengujian terhadap data-data yang digunakan untuk pengujian hipotesis. Adapun analisis data tersebut meliputi: uji normalitas, uji korelasi, dan uji hipotesis. Data diperoleh sebesar 0,973. karena karena $p$ value $=0,973>\alpha=0,05$ sehingga dapat disimpulkan bahwa data mengikuti distribusi normal. Persepsi siswa tentang kompetensi yang dibutuhkan di dunia industri sebesar 0,006. karena karena $p$-value $=0,006<\alpha=0,05$ sehingga dapat disimpulkan bahwa data tidak berdistribusi normal.

Perhitungan korelasi digunakan untuk mengetahui hubungan antara persepsi siswa tentang kompetensi yang dibutuhkan di industri terhadap hasil belajar siswa. Korelasi product momen dari spearman's rho diperoleh harga $r=-0,144$, menunjukan korelasi yang sangat rendah. Hasil perhitungan diperoleh koefisien korelasi sebesar -0,146 dan $t_{\text {hitung }}$ sebesar - 0,87. Pada taraf kepercayaan $95 \%$ dengan $\mathrm{dk}=\mathrm{n}-2$ jadi $\mathrm{dk}-29$, maka dari tabel diperoleh $t_{\text {tabel }}$ sebesar: $t_{(0,95)(29)}=1,7$. Koefisien korelasi antara persepsi siswa tentang 
kompetensi yang dibutuhkan di industri terhadap hasil belajar siswa pada siswa tidak signifikan (tidak mempunyai hubungan yang berarti) pada taraf kepercayaan $97.5 \%$ dengan $\mathrm{dk}=-29$. Tidak terdapat hubungan antara persepsi siswa tentang kompetensi lulusan yang dibutuhkan industri dengan hasil belajar siswa. Hubungan antara persepsi siswa tentang kompetensi lulusan yang dibutuhkan industri dengan hasil belajar adalah negatif dan tidak berarti. Nilai dari koefisien determinasi yaitu 2,1\%. Artinya persepsi siswa tentang kompetensi yang dibutuhkan di industri yang mempengaruhi variabel hasil belajar siswa kelas XIII PPU di SMKN 12 Bandung tahun ajaran 2014/2015 sedangkan variabel sisanya 97,93\% dipengaruhi variabel lain. Hasil perhitungan hipotesis $p-v=0,18>0,05$ maka $\mathrm{H}_{\mathrm{o}}: \mathrm{p}=0$ diterima, dan $\mathrm{H}_{\mathrm{A}}: \mathrm{P} \neq 0$ ditolak. Hubungan antara persepsi siswa tentang kompetensi yang dibutuhkan di industri terhadap hasil belajar siswa tidak signifikan.

\section{PEMBAHASAN}

Hasil analisis data menunjukan bahwa (1) sebaran data persepsi siswa tentang kompetensi lulusan berada pada kategori sedang, (2) sebaran data hasil belajar siswa berada pada kategori tingi, (3) nilai korelasi antara persepsi siswa tentang kompetensi lulusan yang di butuhkan di industri terhadap hasil belajar menunjukan nilai yang sangat rendah.

Berdasarkan hasil pemetaan korelasi variabel persepsi siswa tentang kompetensi yang dibutuhkan di industri terhadap hasil belajar siswa. Diketahui penyebab tidak ada korelasi yang signifikan. Rendahnya pengaruh pengaruh antara persepsi siswa tentang kompetensi yang dibutuhkan di industri terhadap hasil belajar siswa pada siswa kelas XII PPU 1 di SMKN 12 Bandung. Hasil pemetaan terlihat siswa yang memiliki jumlah skort tinggi pada variabel persepsi siswa memiliki nilai hasil belajarnya kecil. Sebaliknya untuk siswa yang memiliki jumlah skort kecil pada variabel persepsi siswa memiliki nilai hasil belajar yang besar. Dengan demikian, bahwa tidak ada kesesuaian antara persepsi siswa dengan hasil belajar (Arikunto, 2009).

Hasil pemetaan tersebut penulis beranggapan bahwa penyebab siswa yang memiliki skort persepsi tinggi. Namun hasil belajarnya kecil salah satunya adalah siswa kurang mendapatkan informasi tentang kompetensi yang dibutuhkan untuk dapat bekerja di industri. Sehingga terjadi kesalahan persepsi yang terbentuk pada siswa yang lebih mengutamakan praktek, dan dengan sekolah di SMK akan mudah untuk bekerja. Persepsi awal tersebut akan berpengaruh pada aspek kognisi, dimana aspek kognisi merupakan aspek yang melibatkan cara berpikir, mengenali, memaknai suatu stimulus yang diterima 
oleh panca indra, pengalaman atau yang pernah dilihat dalam kehidupan sehari-hari. (Hariandja, 2007). Salah satu aspek persepsi adalah interpretasi. Interpretasi merupakan suatu aspek kognitif dari persepsi yang sangat penting yaitu proses memberikan arti kepada stimulus yang diterimanya. Proses interpretasi tersebut bergantung pada cara pendalaman, motivasi, dan kepribadian seseorang (Toha, 2003).

Berdasarkan teori di atas, jika persepsi awal siswa yang beranggapan bahwa SMK lebih mengutamakan pelajaran praktek, menunjukan bahwa siswa tersebut tidak mengalami perubahan atau penambahan stimulus/informasi setelah mengikuti proses pembelajaran. Akibatnya, akan menimbulkan pemaknaan siswa bahwa yang harus dikuasai untuk dapat bekerja adalah mata pelajaran praktek dan cenderung mengabaikan mata pelajaran praktek (Waidi, 2006). Pihak sekolah juga menerima masukan dari pihak industri terkait permintaan dunia industri untuk meningkatkan soft skill siswa terutama masalah disiplin, etos kerja, kreativitas, dan pengetahuan tentang kedirgantaraan yang masih perlu ditingkatkan.

\section{KESIMPULAN}

Kesimpulan penelitian ini, sebagai berikut rata-rata persepsi siswa tentang kompetensi yang dibutuhkan di industri pada skala data menunjukan kategori sedang. Rata-rata hasil belajar siswa pada kategori tinggi. Tidak terdapat hubungan yang signifikan antara persepsi siswa tentang kompetensi lulusan terhadap hasil belajar siswa.

\section{DAFTAR PUSTAKA}

Arikunto, S. (2009). Dasar-dasar Evaluasi Pendidikan. Jakarta: Aneka Cipta.

Dimyati, \& Mujiono. (2006). Belajar dan Pembelajaran. Jakarta: Renika Cipta.

Hamalik, O. (2007). Pengembangan SDM Manajemen Pelatihan Ketenagakerjaan Pendekatan Terpadu. Jakarta: Bumi Aksara.

Hariandja, M. T. E. (2007). Manajemen Sumber Daya Manusia: Pengadaan, Pengembangan, Pengkompensasian, dan Peningkatan Produktivitas Pegawai. Jakarta: PT Grasindo.

Mangkunegara, A.P. (2004). Manajemen Sumber Daya Manusia. Bandung: PT. Remaja Rosdakarya.

Simamora, B. (2001). Memenangkan Pasar dengan Pemasaran Efektif dan Profitabel. Edisi pertama. Jakarta: PT. Gramedia Pustaka Utama. 
Sudjana, N. (2005). Penilaian Hasil Proses Belajar Mengajar. Bandung: PT. Remaja Rosdikarya.

Sugihartono. (2007). Psikologi Pendidikan. Yogyakarta: UNY Pers.

Suharman. (2005). Psikologi Kognitif. Surabaya: Srikandi.

Toha, M. (2003). Perilaku Organisasi Konsep Dasar dan Aplikasinya. Jakarta: PT Raja Grafindo Persada.

Walgito, B. (2004). Pengantar Psikologi Umum. Yogyakarta: Andi.

Waidi. (2006). The Art of Re-engineering Your Mind for Success. Jakarta: Gramedia 